\title{
ENVIRONMENTAL ASSESSMENT FOR MOVING THE PACIFIC NORTHWEST LABORATORY RADON GENERATORS FROM LIFE LIFE SCIENCES LABORATORY II, RICHLAND NORTH AREA, Tก LIFE SCIENCES LABORATORY I, 300 AREA, THEIR CONTINUED USE IN PHYSICAL AND BIOLOGICAL RESEARCH
}

I. C. Nelson

\section{DISCLAIMER}

This report was prepared as an account of work sponsored by an agency of the United States Government. Neither the United States Government nor any agency thereof, nor any of their employees, makes any warranty, express or implied, or assumes any legal liability or responsibility for the accuracy, completeness, or usefulness of any information, apparatus, product, or

Handout process disclosed, or represents that its use would nut infringe privately owned rights. Reference herein to any specific commercial product, process, or service by trade name, trademark, manufacturer, or otherwise does not necessarily constitute or imply its endorsement, recommendation, or favoring by the United States Government or any agency thereof. The views and opinions of authors expressed herein do not necessarily state or reflect those of the United States Government or any agency thereof.

Prepared for

the U.S. Department of Energy

under Contract DE-ACO6-76RLO 1830

Pacific Northwest Laboratory

Richland, Washington 99352 
ENVIRONMENTAL ASSESSMENT

FOR

MOVING THE PACIFIC NORTHWEST LABORATORY RADON GENERATORS

FROM

LIFE SCIENCES LABORATORY II, RICHLAND NORTH AREA,

TO

LIFE SCIENCES LABORATORY I, 300 AREA,

AND

THEIR CONTINUED USE IN PHYSICAL AND BIOLOGICAL RESEARCH

\subsection{INTRODUCTION}

The Pacific Northwest Laborat.ory (PNL) radon generators are a core resource of the overal1 U. S. Department of Energy's (DOE) Radon Research Program and are administratively controlled within the "Radon Hazards in Homes" project. This project primarily focuses on radon exposures of animals and addresses the major biologic effects and factors influencing risks of indoor radon exposures. For example, the "Mechanisms of Radon Injury" and "In vivo/In vitro Radon-Induced Cellular Damage" prujects specifically address the cytogenetic and DNA damage produced by radon exposure as part of a larger effort to understand radon carcinogenesis. Several other ongoing PNL projects, namely: "Biological Effectiveness of Radon Alpha Particles: A Microbeam Study of Dose Rate Effects, " "Laser Measurements of Pb-210," "Radon Transport Modeling in Soils, " "Oncogenes in Radiation Carcinogenes is," "Mutation of DNA Targets," "Dosimetry of Radon Progeny," and "Aerosol Technology Development" also use the radon exposure facilities in the conduct of their work.

While most, but not all, studies in the PNL Radon Research Program are funded through DOE's Office of Health and Environmental Research, PNL al so has ongoing collaborative radon studies with investigators worldwide; many of these use the radon exposure facilities.

\subsection{PURPOSE OF AND NEED FOR PROPOSED ACTION}

The purpose of the proposed action is to provide for relocation of the radon generators to a DOE-owned facility and to continue to provide a controlled source of radon-222 for continued use in physical and biological research. This research involves both in vitro and in vivo experiments using laboratory animals and primary cell lines and is directed primarily toward quantitatively determining the dosimetry of, and the biological response to, radon and radon decay products in order to further evaluate worker and public health and safety issues related to radon in the work place and in the environment. 
The radon generators are presently located in the Life Sciences Laboratory II, which is privately owned by Battelle Memorial Institute (BMI). The radon generating equipment is owned by the U. S. Department of Energy's Pacific Northwest Laboratory, operated by Battelle, Pacific Northwest Division (PNWD). The proposed action is needed in order to discontinue maintaining approximately one curie of DOE-owned radium chloride in liquid solutions, and radon hold-up systems in private facilities within the city limits of Richland, Washington.

\subsection{PROPOSED ACTION}

The proposed action which this Environmental Assessment (EA) addresses is to relocate DOE-owned radon generators from Battelle-owned Life Sciences Laboratory II (LSL-II), Richland North Area, to DOE-owned Life Sciences Laboratory I (LSL-I, also known as the 331 Building), 300 Area, Hanford Site by 1) remodelling four presently unused rooms in LSL-I to essentially the same configuration as in LSL-II; 2) fabricating and installing a radon progeny hold-up ventilation exhaust system; 3 ) installing exposure chambers; 4) removing the radon-222 generators from $L S L-I I ; 5)$ transporting the generators to $(S L-I ; 6)$ installing the generators and connecting them to the hold-up system; 7) decontaminating present LSL-II radon exposure facilities, if necessary; and 8 ) resuming physical and biological research in LSL-I, which began in 1976 in LSL-II, using the radon-222 generators. The preferred alternative for relocation of the radon generators is LSL-I as it is a DOE-owned faciiity, the necessary rooms are empty and available, and other activities occuring in the facility are focused toward radiobiological research. The location of the Hanford Site's $300 \mathrm{Area}$, in relation to the Richland North Area and other areas is shown in Figure 1 and the location of the LSL-I and LSL-II facilities is shown in Figure 2.

\subsection{Description of Radon Generating Equipment}

The radon-generating equipment presently installed in the LSL-II facility consists of nine individual radium-226 chloride solutions (having a total activity level of about one curie), a radon in vitro cell exposure system, radon animal exposure chambers, and radon-progeny hold-up systems (shown schematically in Figure 3 ) that are used in support of physical and biolugical research.

The solutions are stored in glass bottles located in Plexiglas or polycarbonate enclosures vented to the hold-up system, thence to the LSL-II exhaust system. One higher-level solution and several intermediate-level solutions are stored in lead-shielded pigs and are fully enclosed in Plexiglas glove boxes. Access to the radon generators is by using regular glove box gloves or through transfer ports. In addition to the nine generators, there is one source bottle containing about $50 \mathrm{mCi}$ radium-226 chloride solution and one empty (a quondam source) bottle containing residual radioactivity. 


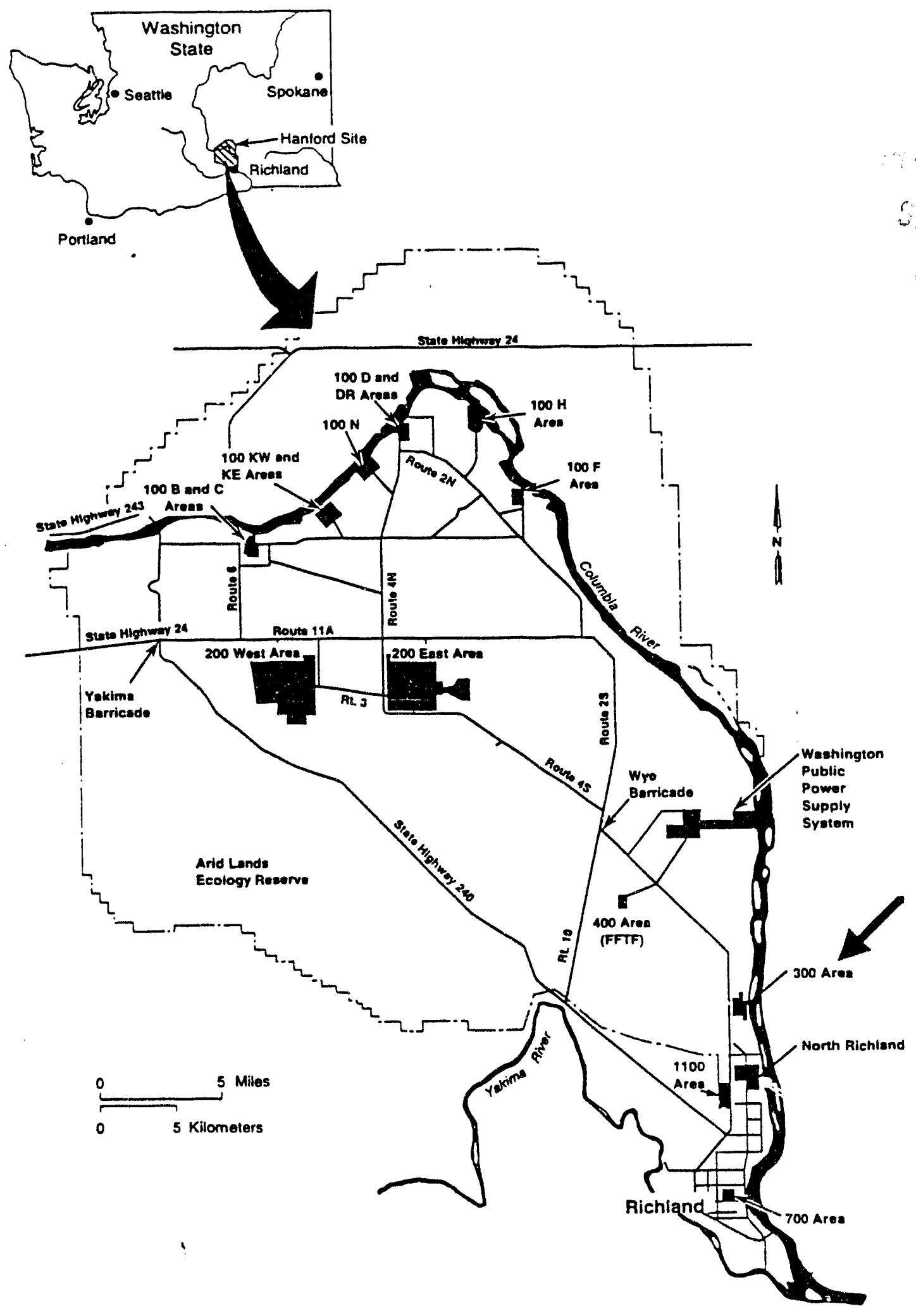

Figure 1. Location of the Hanford Site and the 300 Area. 


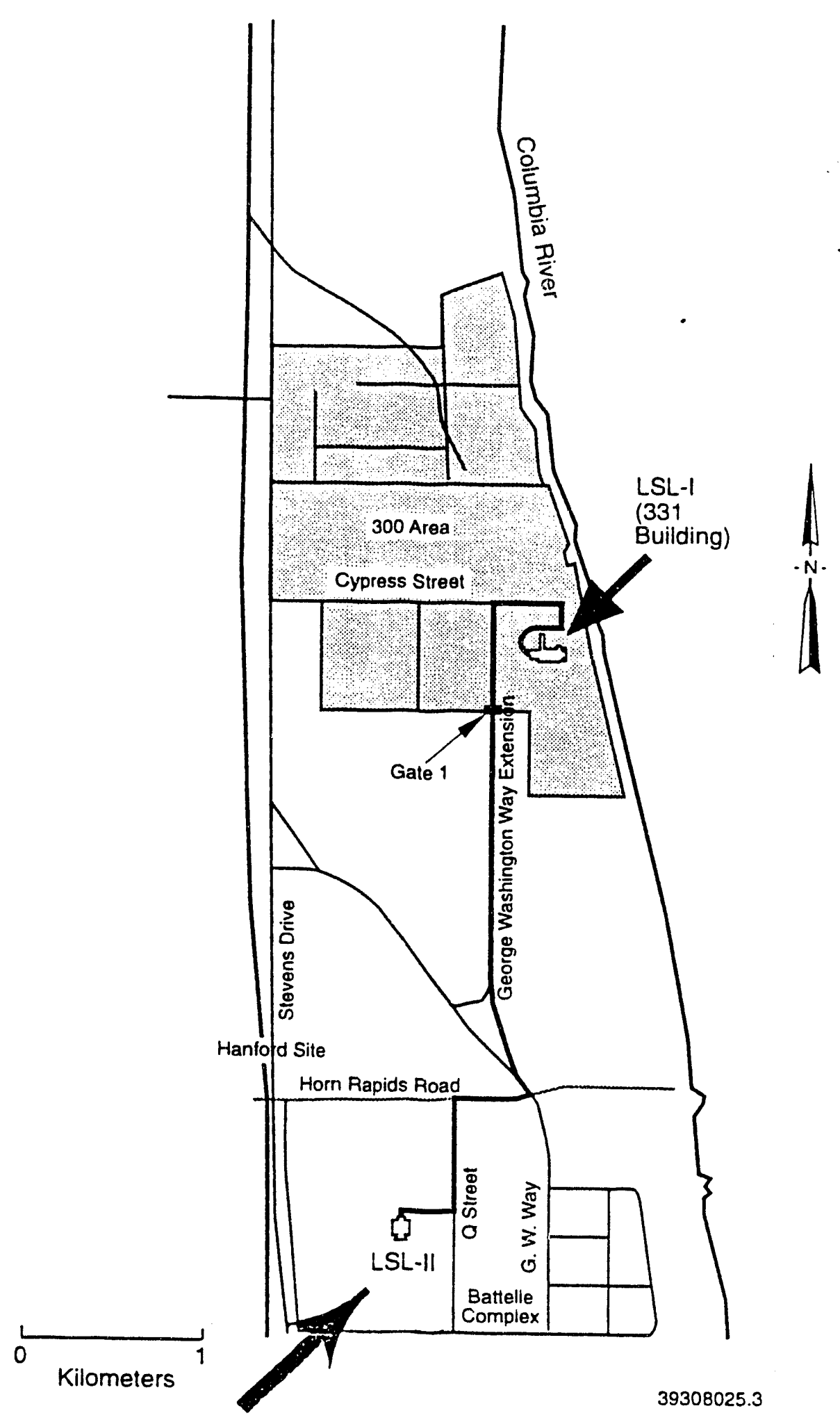

Figure 2. Location of LSL-I and LSL-II. 


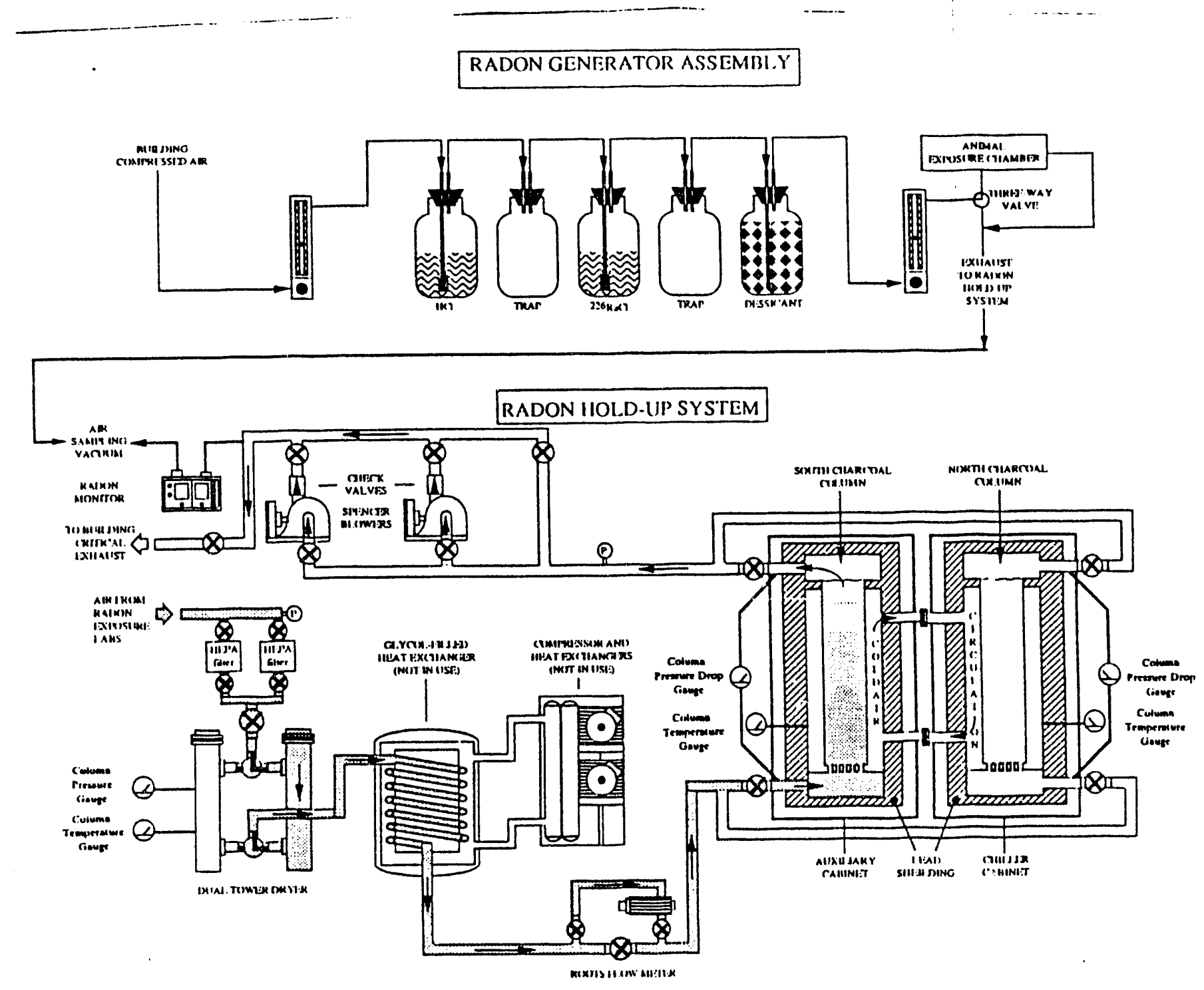

Figure 3. Schematic Drawing of Radon Hold-Up System 
Bottles containing lower-level solutions are stored on laboratory carts, and are set into sheets of Styrofoam to prevent movement or tipping. Each of the carts is housed in an open-topped polycarbonate box over which is placed a removable Plexiglas cover to allow access to the radon generators. A ventilation hose is attached to this cover. The box has doors the full length of one side to allow access to the bottom of the cart.

The nine radium chloride sources generate approximately $130 \mu \mathrm{Ci} / \mathrm{min}$ of radon-222 (222 $\mathrm{Rn})$. The radon is continuously removed from each of the radon generators at an air flow rate of about $150 \mathrm{cc} / \mathrm{min}$. The radon can be routed directly to the radon hold-up system, or can be passed through the animal exposure chamber or cell exposure system before it reaches the radon hold-up system. Exhaust from the radon hold-up system is routed to the LSL-II main vuilding exhaust system, where the air $\left(35 \mathrm{~m}^{3} / \mathrm{s}\right)$ passes through one stage of testable High Efficiency Particulate Air (HEPA) filters prior to entering the exhaust stack and is continuously monitored for radon prior to exit from the building. It is planned that similar conditions, including the hold-up system, would be achieved in LSL-I.

Al1 exhaust from the experiment rooms and from the radon generator enclosures is routed to the main building exhaust system, as is the exhaust from the clean and regulated corridors on either side of these rooms. Exhaust is irawn through an open-faced hood in the experiment rooms, where it is initially HEPA-filtered prior to entering the main exhaust system.

The radon generator and exposure facility has been operating in LSL-II for about 16 years and measurements of radon at the facility exhaust point have consistently been at indour-background levels of $0.5-1.5 \mathrm{pCi} / \mathrm{\ell}$ (Ikenberry 1990).

\subsection{Construction (Remodeling)}

All remodeling would take place within an existing building. The new 7 aboratory would be located in four presently unoccupied rooms in LSL-I (Rooms 195-198; see Figures 4 and 5). Two new doors would be installed, one between Rooms 196 and 198 and one to the adjoining corridor from Room 195. The overall area involved in LSL-I would be about $250 \mathrm{~m}^{2}$. The LSL-II radon hold-up systems presently in rooms 503 and 507 of LSL-II would be replicated in room 197 of LSL-I; the other three rooms in LSL-I would be used for animal and cell exposure apparatus.

Replication of the hold-up system would be accomplished by either moving one of the redundant systems from LSL-II to LSL-I, transporting the sources to their new storage units, and then moving the other system to LSL-I, or by new construction of the hold-up system before transfer. Remodeling as described is anticipated to cost about $\$ 500,000$. 


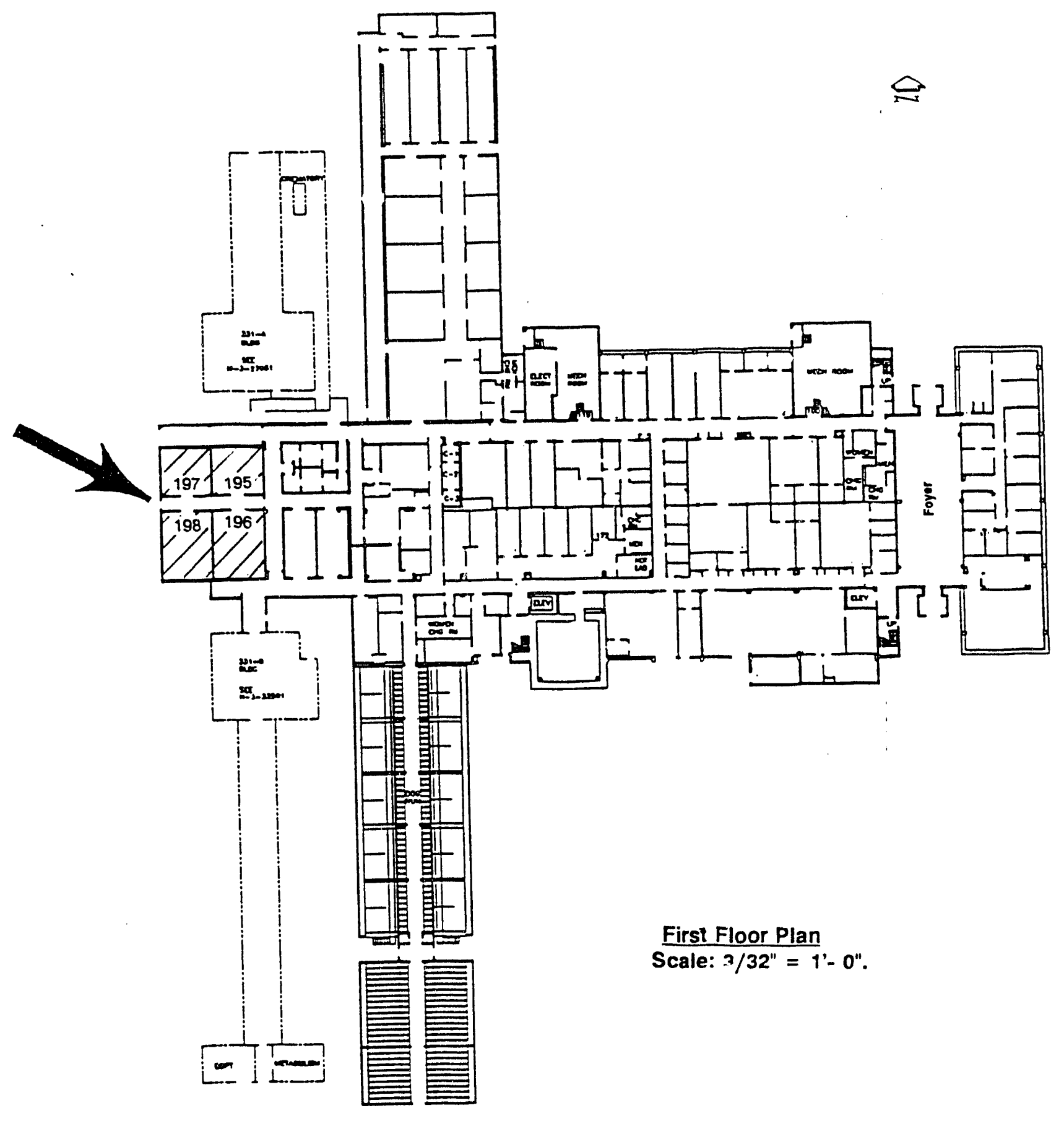

Figure 4. Area to be Remodelled in LSL-I. 


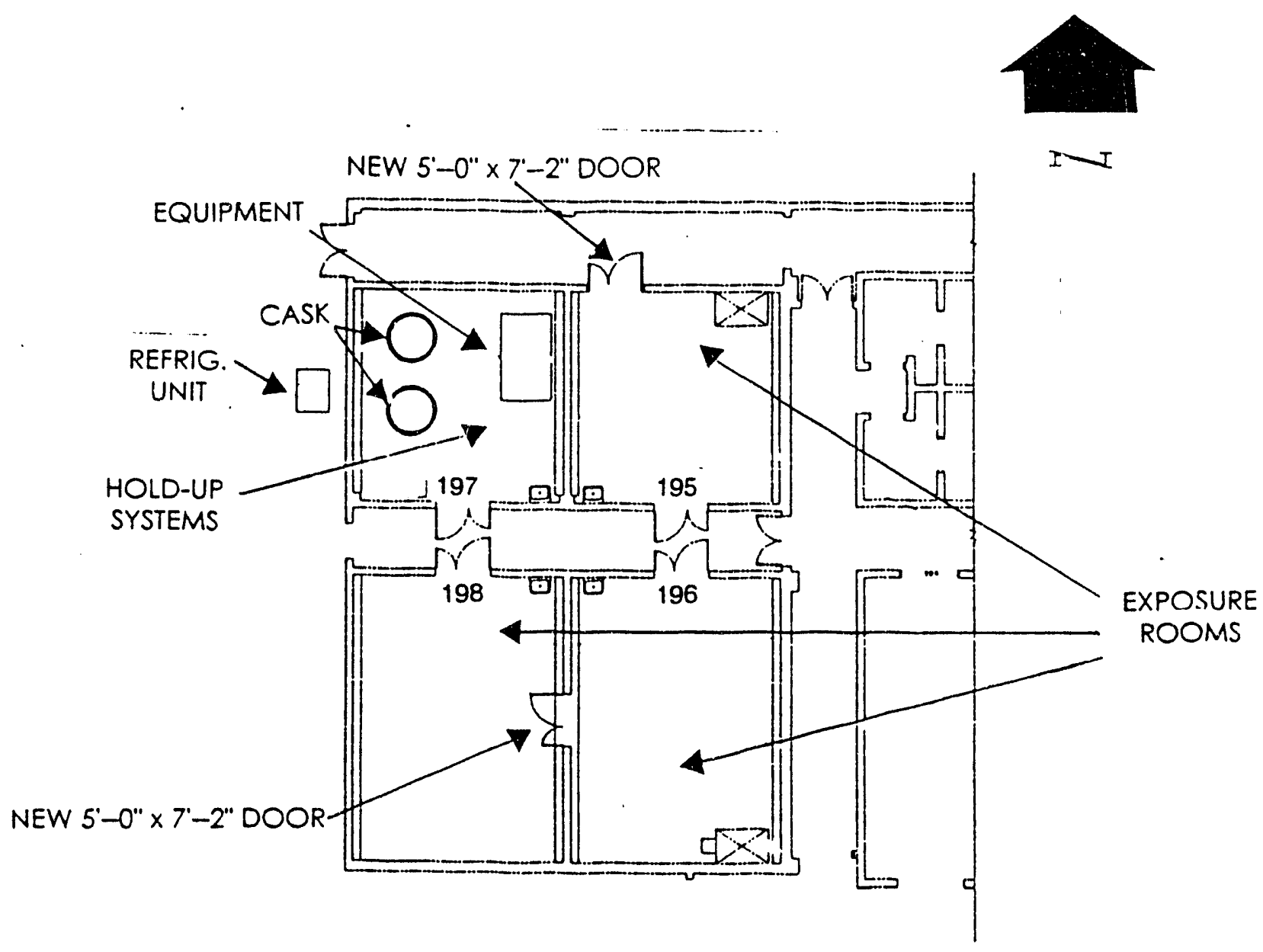

PARTIAL PLAN

SCALE' $1 / 4^{\prime \prime}=1^{\prime}-0^{\prime \prime}$

Figure 5. Rooms to be Remodelled in LSL-I. 
Remodeling may also include fabrication of new exposure chambers; the materials used in construction of the presently used equipment may not meet LSL-I fire protection standards.

There would be no ground-disturbing construction associated with the proposed action and there would be no unique resource requirements associated with the remodeling.

\subsection{Transportation of Generators to LSL-I}

Transportation of the radon generators from LSL-II to LSL-I would take place over the shortest route (about $3 \mathrm{~km}$ ) between the two buildings [see Figure 2 (heavy line marks proposed route)]. A route-specific transportation plan would be developed and approved to move the generators and sources. The transporation of the materials would be an exclusive use shipment that would involve road closure and barricading to protect the public from any releases or exposures. The route would be on private roads (to and on "Q" Street), north to Horn Rapids Road (public), then east to George Washington Way (public), then north along George Washington Way Extension, through Gate 1 (restricted travel) leading directly north to Cypress Street in the 300 Area and then turning east to the LSL-I entrance, then south and around the west side of the building to the unloading area. Horn Rapids Road and George Washington Way would be closed to all traffic while the generators were being moved along them. The actual transit time should take less than one hour and closure of Horn Rapids Road and George Washington Way should require less than 15 minutes. The transportation plan would include an alternate route in the event that an unforeseen blockage of the intended route occurred in order to prevent any delay in transport of the materials once the shipment has begun. The transport of the material would occur during a minimal traffic time to limit any effect on the individuals who would use the public use road.

Transport of the generators and sources would be conducted according to the transportation plan with procedures approved by the PNL transportation and radiation protection specialists. Because the quantities of the source material would be $U$. S. Department of Transportation (DOT) Type B quantities, the packaging would meet the intent for DOT Type B materials. The packaging would be reviewed by the PNL packaging and transportation specialists. The proposed packaging would transport the large radon generator source in its lead-shielded storage container (pig); the smaller liquid sources in glass bottles would be securely capped and transported in their Plexiglas $\$$ or polycarbonate enclosures, all of which would be placed in an additional containment box with approved absorbent material (e.g., diatomaceous earth) to preclude any accidental release and dispersal in the event of a spill. The lead storage container and the containment box would then be secured to the bed of the transport vehicle. An extra precaution would be to perform a dry run of the transport of the materials to familiarize the staff involved with this activity and to identify any possible problems or delays. No credible accide!,t scenarios associated 
with the highly controlled transport of the generators over this short route were identified.

\subsection{ALTERNATIVES TO PROPOSED ACTION}

Alternatives to the proposed action are described in the following subsections.

\subsection{Alternative Radon Generation Processes}

Since the need is for exposure of physical and biological systems to radon-222 and its decay products, and since radon in quantity is obtained only through the decay of radium-226, there is no reasonable alternative to the production of radon via radium-226 generators such as those being used in LSL-II.

\subsection{Alternative Sites}

There are no unique features of the LSL-I facility that would require locating the radon generators in that facility. The generators and laboratory facilities, together with their radon hold-up-for-decay and filtration system could be located in alternative locations, for example, a facility, either existing or to be built, in one of the 200 Areas. The LSL-I location was considered the logical selection because it permitted consolidation of like radiobiolngical research in one facility, and because of the availability of the space for which minimal remodelling would be necessary.

\subsection{No-Action Alternative}

The "no-action alternative" is assumed for purposes of this analys is to be not moving the generators, that is, continuing use of the generators in LSL - II.

\subsection{AFFECTED ENVIRONMENT}

The affected environment associated with LSL-I and LSL-II and their environs are described in the following subsections.

\section{$5.1 \quad$ LSL-I}

As shown in Figure 2, LSL-I is situated in the southeast portion of the 300 Area of the Hanford Site. The 300 Area of the Hanford Site has been an industrialized area for over 40 years.

The principal pathway for possible public exposure to contaminants during operations at the LSL-I would be via routine or accidental release of gases and/or particulates to the atmosphere. The nearest full time resident is assumed, for purposes of impact calculations, to be located about $1.0 \mathrm{~km}$ to the southeast. 
The Columbia River adjoins the 300 Area on the east and is about 100 meters from LSL-I. The portion of LSL-I to house the radon generators is located above the level of the probable maximum flood (DOE 1986) and is not situated un any wetlands. LSL-I is not within the area included in the Public Law 100-605 Columbia River Study.

Several archaeological surveys have been conducted on the Hanford Site (Chatters 1989) and there are no known archaeological or cultural resources in the vicinity of LSL-1. Since the proposed action would be performed within an existing structure and not involve breaking ground, there would be no opportunity for discovery of such resources.

Based on Site studies (Cushing, et. al. 1992) there are no threatened or endangered species known to exist or frequent the area in the vicinity of LSL-I.

\section{$5.2 \quad L S L-I I$}

LSL-II is located within the City of Richland, Washington, about $0.5 \mathrm{~km}$ from the northeastern limit of the city, and about $2.5 \mathrm{~km}$ south of LSL-I. The area immediately adjacent to LSL-II consists of additional Battelle private property on which other research and support facilities are situated. The nearest public street is George Washington Way which runs north and south about $0.4 \mathrm{~km}$ east of LSL-II. Other research, engineering and support facilities operated by various entities, e.g., the Port of Benton and Washington Public Power System offices, are located along the east side of George Washington Way in the vicinity of LSL-II. The Columbia River flows north to south about $1.0 \mathrm{~km}$ to the east of LSL-II. The nearest full time resident is assumed, for purposes of impact calculations, to be located about $1.5 \mathrm{~km}$ to the east.

\subsection{ENVIRONS OF LSL-I AND LSL-II}

The affected environment includes the LSL-I and LSL-II Buildings, the remainder of the Hanford Site, and its environs as indicated in Figure 1. The Hanford Site lies within the semi-arid (average precipitation $15 \mathrm{~cm} / \mathrm{yr}$ ) Pasco Basin of the Columbia Plateau in southeastern Washington State. The Hanford Site occupies an area of about $1450 \mathrm{~km}^{2}$ north of the confluence of the Yakima and the Columbia rivers. Historically this land, with restricted public access, provided a buffer for the smaller areas used for production of nuclear materials, waste storage and disposal. Only about six percent of the land area has been disturbed and is actively used (Cushing 1992).

Adjoining lands to the west, north, and east are principally range and agricultural land. The cities ("Tri-Cities") of Richland, Kennewick (Benton county), and Pasco (Frankl in county) constitute the nearest population center and are located southeast of the Hanford Site. The population within $80 \mathrm{~km}$ of the Hanford Site is about 340,000.

Outdoor ambient concentrations of naturally occurring radon-222 on the North American continent range typically from 0.1 to $0.2 \mathrm{pCi} / \ell$ and, on 
avarage, naturally occurring concentrations of radon indoors are on the order of ten times higher. The annual effective dose equivalent to individuals from radon is about $200 \mathrm{mrem}$ (NCRP 1987). Based on a population of 340,000 in the nearby Hanford environs, $200 \mathrm{mrem} / \mathrm{yr}$ would result in 68,000 person-rem/yr to that population which, using a conversion factor of $5 \times 10^{-4}$ cancer fatalities per person-rem, would imply 34 cancer fatalities per year from this component of natural background radiation.

A more complete characterization of the Hanford Site may be found in Hanford Site National Environmental Policy Act (NEPA) Characterization (Cushing 1992).

\subsection{ENVIRONMENTAL. IMPACTS OF THE PROPOSED ACTION}

Potential environmental impacts tinat might be associated with remodeling of LSL-I and instaliation of the radon gas hold-up system, transportation of the generators to their new location, and routina operation of the reinstalied generators are described in the following subsections.

\subsection{Construction Impacts}

Although not quantified, remodeling of portions of a $250 \mathrm{~m}^{2}$ area in LSL-I would result in the production of minor amounts of dust, noise, and debris. Compliance with OSHA regulations would control impacts of dust and noise on workers. Waste construction materials would be disposed of in an existing Hanford landfill.

\subsection{Operational Impacts}

Operational (environmental) impacts associated with routine operation of the facility and with hypothetical, but plausible, accidents are described in this section. Impacts are based on operation experience in LSL-II, but since the generating and exposure equipment would be essentially replicated in LSL-I, the implications of generator operation in LSL-I are taken to be equivalent tc the experience for generator operation in LSL-1I. The radon generator and exposure facility has been operating in LSL-II for about 16 years and measurements of radon at the facility exhaust point have consistently been at indoor-background levels of $0.5-1.5 \mathrm{pCi} / \ell$ (Ikenberry 1990). None of the accidents postulated have occurred in 16 years of radon generator operation in LSL-II.

\subsubsection{Public Health and Safety - Routine Operations/Postulated Accidents}

Impacts on public health and safety from routine operations and postulated accidents during operations are presented in the following subsections. 


\subsubsection{Routine Radon Releases}

Although radon-222 gas is generated in the facility, after it passes through the experiment/exposure chambers it is held up for radon decay and the decay products are filtered from the air stream. Radon is not routinely released in amounts measurable above indoor background levels of $0.5-1.5 \mathrm{pCi} / \mathrm{l}$.

\subsubsection{Accidental Radon Release}

A scenario was postulated to bound likely impacts of accidental releases of radon circumventing the radon hold-up system. In that scenario it was assumed that complete failure of the radon hold-up system took place, with the result that $150 \mu \mathrm{Ci} / \mathrm{min}$ (based on $1.2 \mathrm{Ci}{ }^{226} \mathrm{Ra}$ ) of ${ }^{222} \mathrm{Rn}$ were released to the atmosphere. A member of the public was postulated to be in the general area outside the facility at an average distance of 100 meters for 8 hours during the release. The effective dose equivalent to this individual was calculated to be $18 \mathrm{mrem}$ (Ikenberry 1990). As stated above, the annual effective dose equivalent to individuals from ambient concentrations of naturally occurring radon and radon decay products is about $200 \mathrm{mrem}$. A dose of $18 \mathrm{mrem}$ to the maximally exposed individual as a result of this postulated, but highly unlikely, accidental exposure scenario would amount to a one-time dose of about $6 \%$ of the individual's annual dose from naturally occurring sources. Using a dose conversion factor of $5 \times 10^{-4}$ latent cancer fatalities per person-rem, $9 \times 10^{-6}$ cancer fatalities would be implied by such a dose.

\subsubsection{Accidental Radium Release}

A scenario was postulated wherein airborne radium chloride from a $1.9 \mathrm{mCi}$ radon generator that was dropped and broken was assumed to be transported through the LSL-II ventilation system, including two stages of HEPA filters, before being released. (The lower-level generators are believed more likely to be involved in accidents because they are provided with less restraints and confinement.) A member of the public is assumed to be in the general area outside the facility for 8 hours during the release, at an average distance of 100 meters. The calculated effective dose equivalent to a member of the public from such a release was $0.00001 \mathrm{mrem}$ (Ikenberry 1990). Using a dose conversion factor of $5 \times 10^{-4}$ laint cancer fatalities per person-rem, $5 \times 10^{-12}$ cancer fatalities would be implied by such a dose. 


\subsubsection{Worker Health and Safety - Routine Operations/Postulated Accidents}

Potential impacts on worker health and safety during routine operation and postulated accidents are described in the following subsections.

\subsubsection{Routine Operations}

It is expected that two individuals would perform the experiments using the radon sources. Experience in such experiments in the LSL-II laboratory suggests that the highest exposure to workers would be about $250 \mathrm{mrem} / \mathrm{yr}$ and that the annual collective worker dose would be about 0.4 person-rem. Assuming a 20 year operating period and a dose conversion factor of $4 \times 10^{-4}$ latent cancer fatalities per worker-rem, $3 \times 10^{-3}$ cancer fatalities would be implied by such a dose.

\subsubsection{Accidental Radon Release}

In this postulated accident scenario it was assumed that the tubing connecting the $700 \mathrm{mCi}$ radon generator to the animal exposure chamber, or back to the radon hold-up system, was broken or came loose. Radon-222 was pumped into the room air at a flow rate of $150 \mathrm{cc} / \mathrm{min}$, and at an activity rate characteristic of a $700 \mathrm{mC} \cdot{ }^{226} \mathrm{Ra}$ source. As an upper 1 imit, a worker was assumed to be exposed for 8 hours under upset ventilation conditions. Under these conditions it was determined that the worker would receive a dose of $30 \mathrm{mrem}$ effective dose equivalent (Ikenberry 1990). Such a dose would amount to $1 \%$ of the annual allowable worker dose. Using a dose conversion factor of $4 \times 10^{-4}$ latent cancer fatalities per worker-rem, $1 \times 10^{-5}$ cancer fatalities would be implied by such a dose.

\subsubsection{Accidental Release of Radium}

The $1.9 \mathrm{mCi}$ radon generator was assumed to be dropped and broken. A worker in the room was exposed to airborne ${ }^{226} \mathrm{Ra}$ for two minutes before exiting the room. Under these conditions it was determined that the worker would receive a dose of 40 mrem effective dose equivalent (Ikenberry 1990), or about 1\% of the annual allowable worker dose. Using a dose conversion factor of $4 \times 10^{-4}$ latent cancer fatalities per worker-rem, $2 \times 10^{-5}$ cancer fatalities would be implied by such a dose. Exposure to workers to radiation during clean-up of such a spill would be controlled in accordance with DOE Orders and the as low as reasonably achievable (ALARA) principle. 


\subsubsection{Air Quality}

In the proposed action there would be only trace amounts of radon and/or its decay products that would escape the hold-up-for-decay and filtration system. There would be minimal impacts on air quality from such amounts escaping to the atmosphere; the proper environmental regulations and permit requirements would be in place as discussed in Section 10. The radon generator and exposure facility has been operating in LSL-II for about 16 years and measurements of radon at the facility exhaust point have consistently been at indoor-background levels of $0.5-1.5 \mathrm{pCi} / 1$ (Ikenberry 1990).

\subsubsection{Water Quality}

There are no materials released to surface or ground during normal operations associated with the proposed action, hence there would be no effects on surface water or groundwater quality.

\subsubsection{Ecological Systems and Threatened and Endangered Species}

In the absence of any additional structures, transportation, or effluents there would be no effects on local ecosystems associated with the proposed action.

\subsubsection{Cultural Resources}

In the absence of known cultural resources and the lack of opportunity for discovery of unknown resources, there are no implications of impacts on cultural resources associated with the proposed action.

\subsubsection{Socioeconomics}

Since only 1 to 3 individuals would likely be associated with the radon generators, there is no basis for occurrence of socioeconomic effects.

\subsubsection{Waste Management and Disposal}

Charcoal filters used in the radon decay product filter system and HEPA filters used in the central LSL-I building ventilation exhaust would eventually require replacement and the spent filters would be disposed of in an approved low-level disposal site on the Hanford Site. Animal carcasses and other waste materials incidental to the in vivo and in vitro experiments would be disposed of in an approved low-level waste disposal site on the Hanford Site.

At such time as the radon generators are determined to be no longer needed for experimental work at Hanford, the sources could be transferred to some other DOE laboratory or university. For 
all practical purposes, the radon generators have an indefinite life. In the unlikely event that no alternative uses were found, the sources would be isolated from the human environment in an appropriate repository. The LSL-I laboratory would be decontaminated, if necessary, and the wastes so produced disposed of in a low-level waste disposal site at the Hanford Site.

\subsection{ENVIRONMENTAL IMPACTS OF ALTERNATIVES TO THE PROPOSED ACTION}

If the radon generators were relocated to some other existing building on the Hanford Site, doses to the public from either routine operations or postulated accidents (though trivial in either case) would most likely be less because of the potential to increase distance to receptors. Operating staff would have a longer commute to work. Other environmental aspects would be expected to be invariant with site.

If a new facility were to be built, minor impacts associated with additional ground disturbance and construction activities would occur that would be larger than those associated with remodelling LSL-I. Other impacts would be expected to be the same as for radon generator operation in existing buildings. As a consequence, alternative sites were dismissed from detailed analysis.

\subsection{IMPLICATIONS OF THE NO-ACTION ALTERNATIVE}

If the no-action alternative (continue generator use in LSL-II) were adopted, the minor effects associated with remodelling LSL-I and transporting the radon generators to LSL-I would not take place; operational effects would continue at present levels. It should be noted that adopting this alternative would mean that DOE-owned radium solutions and associated systems would remain on private property within the boundaries of the City of Richland, against the owner's recommendations.

\subsection{CUMULATIVE IMPACTS}

Routine operation of the radon generators would result in a collective worker dose of about 0.3 person-rem/yr, which would not add significantly to the annual collective Hanford worker dose of about 600 person-rem effective dose equivalent. There would be no measurable addition to the collective population dose of about one person-rem/yr (Woodruff and Hanf 1992) effective dose equivalent due to other activities associated with the Hanford Site. The collective population dose from natural background is approximately 100,000 person-rem/yr which using a conversion factor of $5 \times 10^{-4}$ cancer fatalities per person-rem would imply 50 cancer fatalities per year in this population from all sources of natural background radiation. 


\subsection{APPLICABLE ENVIRONMENTAL REGULATIONS AND PERMIT REQUIREMENTS}

It is DOE's policy to conduct its operations in compliance with the letter and spirit of applicable environmental statutes, regulations, and standards (DOE Order 5400.1). Movement and subsequent operation of the radon generators in LSL-I would meet the requirements of all applicable environmental laws, regulations and permits.

Approval may be required by the Environmental Protection Agency pursuant to the Clean Air Act under the National Emission Standards for hazardous Air Pollutants regulations ( 40 CFR 61) for the construction of a new source (or relocating an existing source) of hazardous air pollutants (radionuclides). Permitting or approval under the State of Washington radionuclide air emissions program may also be required.

\subsection{LIST OF PERSONS AND AGENCIES CONSULTED}

The State of Washington Department of Ecology, the Yakima Indian Nation, the Confederated Tribes of the Umatilla Reservation, the Wanapum Band, and the Nez Perce Tribe were provided with an advance copy of this Environmental Assessment for their review and comment before publication.

\subsection{REFERENCES}

Chatters, J. C., Editor. 1989. Hanford Cultural Resources Management Plan. PNL-6942. Pacific Northwest Laboratory, Richland, Washington.

Cushirg, C. E., Editor. 1992. Hanford Site National Environmental Policy Act (NEPA) Characterization. PNL-6415 Rev. 5, Pacific Northwest Laboratory, Richland, Washington.

U. S. Department of Energy. 1986. Environmental Assessment, Reference Repository Location, Hanford Site, Washington. DOE/RW-0070, U. S. Department of Energy, Washingtor, D. C.

Ikenberry, T. A. 1990. Letter Report: T. A. Ikenberry to W. J. Bair, Radiological Hazard Evaluation for the $L S L-I I$ Radon Generators. Pacific Northwest Laboratory, Richland, Washington.

National Council on Radiation Protection and Measurements. 1987. Exposure of the Population of the United States and Canada from Natural Background Radiation. NCRP Report No. 94. Bethesda, Maryland.

Woodruff, R. K. and Hanf, R. W., Eds. 1992. Hanford Site Environmental Report for Calendar Year 1991. PNI-8148. Pacific Northwest Laboratory, Richl and, Washington. 


\section{U. S. Department of Energy}

Finding of No Significant Impact

Moving the Pacific Northwest Laboratory Radon Generators from

Life Sciences Laboratory II, Richland North Area, to

Life Sciences Laboratory I, 300 Area, and

Their Continued Use in Physical and Biological Research

AGENCY: U. S. Department of Energy.

ACTION: Finding of No Significant Impact.

\section{SUMMARY:}

The U. S. Department of Energy (DOE) has prepared an Environmental Assessment (EA), DOE/EA-XXX, on moving the Pacific Northwest Laboratory (PNL) radon generators from Battelle Memorial Institute-owned Life Sciences Laboratory II (LSL-II), Richland North Area to DOE-owned Life Sciences Laboratory I (LSL-I, also known as the 331 Building), 300 Area, Hanford Site, Richland, Washington and their continued use in physical and biological research. Based on the analyses in the EA, DOE has determined that the proposed action is not a major federal action significantly affecting the quality of the human environment, within the meaning of the National Environmental Policy Act (NEPA) of 1969. Therefore, the preparation of an environmental impact statement is not required and the Department is issuing this Finding of No Significant Impact (FONSI). 


\section{DESCRIPTION OF THE PROPOSED ACTION:}

The proposed action which this $E A$ addresses is to relocate DOE-owned radon generators from Battelle-owned LSL-II, Richland North Area to DOE-owned LSL-I, 300 Area, Hanford Site by 1) remodeling four presently unused rooms in LSL-I; 2) fabricating and installing a radon progeny hold-up ventilation exhaust system; 3) installing exposure chambers; 4) removing the radon-222 generators from :SL-II; 5) transporting the generators to $L S L-I ; 6)$ installing the generators and connecting them to the hold-up system; 7) decontaminating present LSL-II radon exposure facilities, if necessary; and 8) resuming physical and biological research in LSL-I, which began in 1976 in LSL-II, using the radon-222 generators.

\section{ALTERNATIVES:}

other technologies for producing radon are not available. The possibility of alternative locations for the radon generators and exposure chambers on the Hanford Site was noted, but no environmental or technical advantage could be found and hence alternative sites were not considered in detail. The "no-action" alternative would amount to continuing use of the generators in LSL-II, selection of which would result in continued location of DOE-owned radium solutions and associated equipment in private facilities within the boundaries of the City of Richland against the owner's recommendations.

\section{ENVIRONMENTAL IMPACTS:}

Environmental impacts of the proposed action were determined to be limited principally to radiation exposure of workers, which, however, were found to be sma11. Individual worker dose was estimated to be no more than $0.25 \mathrm{rem} / \mathrm{yr}$ 


\section{DETERMINATION:}

The proposed remodeling of LSL-I, installing the radon generators, and continuing with ongoing studies being conducted in LSL-II does not constitute a major federal action significantly affecting the human environment within the meaning of the National Environmental Policy Act. This finding is based on the analyses in the EA. Therefore, an Environmental Impact Statement for the proposed action is not required.

PUBLIC AVAILABILITY: Copies of the EA (DOE/EA-XXX) are available from:

Joseph J. Sutey, Director

Laboratory Management Division

U. S. Department of Energy

Richland Operations office

P. 0. Box 550, MSIN A5-90

Richland, Washington 99352

(509) $376-7770$

For further information regarding the DOE NEPA process, contact:

Carol M. Borgstrom, Director

Office of NEPA Oversight

$U$. S. Department of Energy

1000 Independence Avenue, S. W.

Washington, D. C. 20585

(202) $586-4600$ or $(800) 472-2756$

Issued in Washington, D. C., this day of September 1993.

Peter N. Brush

Acting Assistant Secretary

Environment, Safety and Health 
and the collective worker dose was estimated to be about $0.4 \mathrm{man}-\mathrm{rem} / \mathrm{yr}$. No health effects would be expected. Doses to the public from routine operations were calculated to be extremely small fractions of natural background. Even in the unlikely event of accidentally by-passing the radon progeny hold-upfor-decay system, the dose to the maximally exposed individual was less than $10 \%$ of the individual's annual exposure from naturally occurring radon. Such an accident has not occurred in the 16 years of operation in LSL-II. No health effects among the general public would be expected. Implementation of the proposed action would not result in any impacts on cultural resources, threatened and endangered species, air or water quality, socioeconomic conditions, or waste management. 

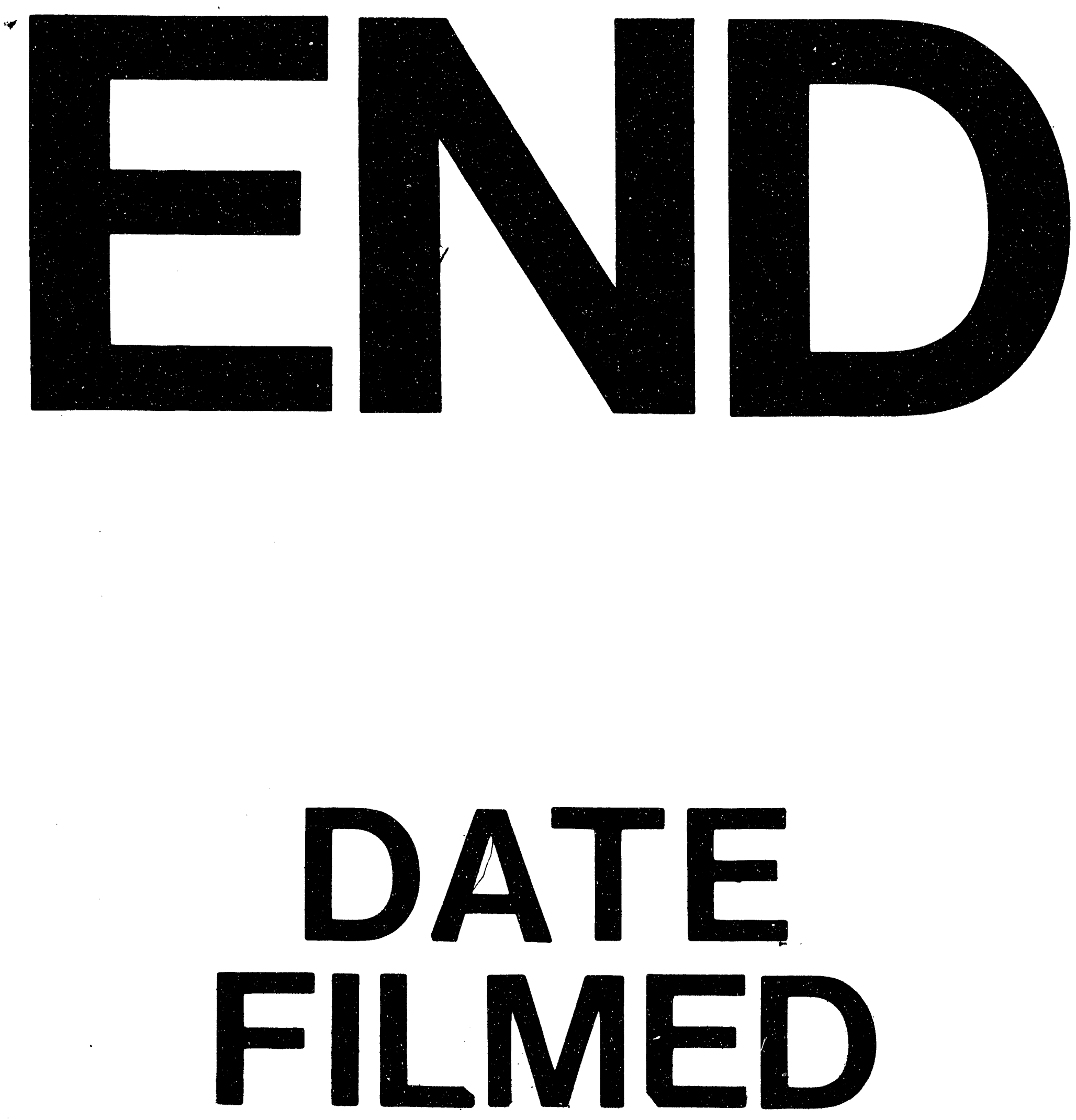

I

$$
11 / 02193
$$


